\title{
Realism in the Trans ASEAN Gas Pipeline Project
}

\author{
Rahmadha Akbar Syah ${ }^{1, *}$, Zaki Khudzaifi Mahmud ${ }^{1}$ \\ ${ }^{1}$ Universitas Pertamina, Indonesia \\ Received 26 April 2019; Accepted 10 August 2019 \\ Available online 31 August 2019
}

\begin{abstract}
To improve connectivity and energy security, especially natural gas, Southeast Asian countries, under the cooperation of Association of Southeast Asian Nations (ASEAN), are trying to build a gas pipeline that stretches from Indonesia to Myanmar. The project is called the Trans ASEAN Gas Pipeline (TAGP) under the ASEAN Plan of Action for Energy Cooperation (APAEC) scheme. However, regional countries are still dealing with their domestic problems, and there are fears that TAGP is detrimental to producer countries, resulting in the delay of this project as much by as four years - from 2020 to 2024. The uncertainty of the TAGP project further emphasizes that there is a tendency for countries not to adhere to the ASEAN forum's agreements. Especially if it has to be juxtaposed with the Russian Gas Pipeline project which was built to distribute natural gas to Western European countries, TAGP is still far behind. In designing this paper, the authors use qualitative methods through literature studies by referring to the realism approach of International Relations to dissect TAGP problems. Furthermore, the author also feels the need to accommodate the neorealism approach to be used as a supportive approach in looking at the issues of disobedience in regional countries in supporting the TAGP scheme. Also, the authors conducted a brief comparison between TAGP and the Russian Gas Pipeline to be used as a case study analysis material that would later provide answers of why TAGP failed to go as planned.
\end{abstract}

Keywords: realism, neorealism, TAGP, Russian Gas Pipeline

\section{Introduction}

Right now, Southeast Asia has undergone significant changes and significant developments towards a new, more integrative and forward-looking stage through the ASEAN community. According to the Kemlu/MoFA Indonesia through ASEAN Selayang Pandang $21^{\text {st }}$ edition, the ASEAN Community aims to create a forward-looking society, living in a peaceful, stable and prosperous environment, which is united by dynamic partnership relationships and creating caring communities (Kementerian Luar Negeri, 2015). Economic improvements in regional countries have also accompanied these changes and developments. In the last 15 years, the average ASEAN economy grew 5.5 percent, higher than global economic growth of 3.9 percent (Anastasia, 2017). However, the economic growth of ASEAN countries is in line with large energy consumption as well; fossil energy use increases by $7.5 \%$ annually to reach 620.37 million tons. Therefore, it is not surprising that ASEAN's energy growth from 2007 to 2015 is higher than the average world growth, which is $3.6 \%$ per year compared to $1 \%$. As a result, the region's topography of energy experienced significant changes during this period. Even for 2015 to 2040, in the same scenario, if there are no changes to business as usual (BAU), the ASEAN energy landscape is projected to increase by 2.4 times in the final energy consumption unit (Total Final Energy Consumption - TFEC) and 2.3-fold in the total primary energy supply unit (Total Primary Energy Supply - TPES) in 2040. The increase in TFEC value to 619 million tons of oil equivalent (Million tonnes of oil equivalent - Mtoe) is primarily driven by the industrial sector, transportation, and household (ASEAN Center for Energy, 2017). This increase indicates that there is a correlation regarding economic growth, which can encourage high energy demand.

\footnotetext{
* Corresponding author

E-mail address: rahmadhaakbar@gmail.com
} 
To improve energy security in the region, especially in achieving natural gas needs, ASEAN under the pillar of the ASEAN Community Economy seeks to form a master plan for cooperation between member countries in the construction of gas pipelines from Indonesia to Myanmar. This project is called the Trans ASEAN Gas Pipeline (TAGP) which will be achieved through interconnection of infrastructure, as well as connectivity through the regasification terminal for liquid natural gas (LNG) to enable gas to be transported across the interconnection via pipelines. However, due to the difficulty of ASEAN in harmonizing the national interests of member countries into a common interest, the implementation of projects that should have been completed in 2020 is extended to 2024. In this paper, the authors will further explain why TAGP, in its implementation, tends to be uncertain.

\section{Theoretical Framework}

As a guide for determining the direction of making this paper, there is a conceptual and theoretical implementation that can be academically accounted for and its validity. This section will cover the concepts and theories of realism that refer to the analysis of David Baldwin through his Neorealism and Neoliberalism Contemporary Debate book and supported by analysis of realism through Robert Jackson and Georg Sørensen's Introduction to International Relations. The concepts and theories will be use as an analytical tool to identify the underlying factors why TAGP project is not able to complete in time. The authors use realism because of its ownership of foreign policy doctrines based on national interests and security. States will abandon all international agreements if they are not linear with the national interest. Thus realism can dissect the behavior of gas-producing countries which are more concerned with supply for domestic needs rather than having to export and carry out natural gas connectivity between regional countries under the TAGP scheme. Besides, the author also needs to accommodate the neorealism approach in order to provide a supporting picture of why regional countries tend not to care about TAGP projects under ASEAN control. Neorealism in this paper refers to the relative and absolute gains in following international agreements/cooperation. The relative gains occurs when natural gas producing countries are concerned about the price and quantity that will be agreed upon if the implementation of TAGP project is successful. Therefore, gasproducing countries will experience two losses. The first one is a reduced domestic supply because there will be an agreement to supply gas to ASEAN countries. The second one is the uniformity of natural gas prices. This scenario further explains the absence of absolute benefits in the TAGP agreement.

Data sources used in this paper are research reports and scientific studies that have been carried out before, along with books, scientific journals, and news that is related to the topic of the paper.

\subsection{Theory and Approach}

The approach of realism is one of the biggest approaches in the study of International Relations. The realism approach focuses on basic political values related to national security and the survival of a country (Baldwin, 1993). Realism itself has the assumption that the international order is in the form of anarchy, and the state is the strongest entity where there is no greater power over the state. Running from these assumptions, realists give centrality to the state as the main actor in world politics and power as an important thing for a country to achieve its interests amid an anarchic world order (Jackson and Sørensen, 2009). Therefore, international politics is described by realists as an arena of power politics competition between countries to defend their respective interests.

Whereas the neorealism approach focuses its analysis on the international structure, which is considered as the place of competition for the countries, which causes the structure to draw closer to the system of anarchy. For neorealism, the state is a seeker of power and is aware that security is not caused by human nature but rather is caused by an international structure that encourages them to do so (Jackson and Sørensen, 2009). This view makes neorealism tend being 'antipathy' towards neoliberals. Neorealists do not deny all possibilities for cooperation between countries, whether through international organizations or regimes, but they continue to argue that cooperating countries 
will always try to maximize their relative strength and defend their national interests, which indicates that there is no absolute interest in cooperation between countries.

\section{Analysis}

\subsection{Trans ASEAN Gas Pipeline}

The need to create a clean environment from harmful carbon emissions is a significant issue in the 21 st century. The Southeast Asian region is no exception, which is also affected by global warming and the impact of the greenhouse gas effect. The Paris Agreement on Climate Change has established a global action plan that needs to be implemented by member countries, including ten ASEAN countries to realize a low carbon plans. Referring to the ASEAN Community's Road To Low-Carbon article, realizing low carbon technology for this region can be done through the promotion of the development and efficient use of natural resources - by increasing cross-border energy trade. One of the energy trades that can increase efficiency is the Trans ASEAN Gas Pipeline project. Besides, this project is also believed to increase the energy sustainability of member countries. The 2004-2009 ASEAN Plan of Action for Energy Cooperation (APAEC) explains the policy regarding the TAGP project. Such as strengthening regional energy security; improving integration of regional energy infrastructure; creating responsive regional energy policies that gradually encourage market reform, liberalization and a sustainable environment; involvement of private sectors to secure regional energy reserves. The scope of ASEAN cooperation in this field covers issues: (i) energy security; ii) construction of electricity networks (Power Interconnection); iii) energy efficiency; (iv) regional policies in the energy sector; (v) research and development of renewable energy (Kemlu, 2015). In the APAEC action plan, there are three legal bases, one of which is the MoU on Trans ASEAN Gas Pipeline. The ASEAN Secretariat, in its report, Master Plan on ASEAN Connectivity, confirms that the TAGP Masterplan must be able to be completed by 2020 .

The Association of Southeast Asian Nations, in its report called "Trans ASEAN Gas Pipeline: Securing Long Term Energy Supply for the Region," said that until the end of 2012, ASEAN had 7.5 trillion cubic meters of gas reserves, representing $3.5 \%$ of the total world. Over the past two decades, gas production in ASEAN has doubled and will grow 30\% over the next 20 years. Therefore, making ASEAN the main exporter of LNG to the global market, unfortunately, due to the region's increasing demand for natural gas, several ASEAN countries have begun importing LNG. For this reason, it needs to be put in mind for member countries to increase domestic demand through the TAGP interconnection. Based on the ASCOPE TAGP Master Plan, TAGP will combine many individual projects, which involve the construction of around 4,500 kilometers of pipelines, especially underwater pipes worth around 7 billion USD. The TAGP project provides an opportunity to involve private entities in terms of investment, including financing and technology transfer. Also, gas pipelines offer significant benefits, both in terms of security, flexibility, and quality of energy supply - this will indirectly encourage the movement of gas trade among regional countries. The projects included in the TAGP collaboration consist of 11 corridors, namely Singapore - Malaysia $(5 \mathrm{~km})$, Myanmar - Thailand (470 km), Myanmar - Thailand (340 km), West Natuna - Singapore $(660 \mathrm{~km})$, West Natuna - Duyong (100 km), Cambodia - Malaysia $(250 \mathrm{~km})$, South Sumatra - Singapore (470 $\mathrm{km})$, Cambodia - Vietnam $(250 \mathrm{~km})$, Malaysia - Thailand JDA (270 km), Singapore - Malaysia (4 $\mathrm{km})$, and M9 - Thailand (250 km), shown in Figure 1. 


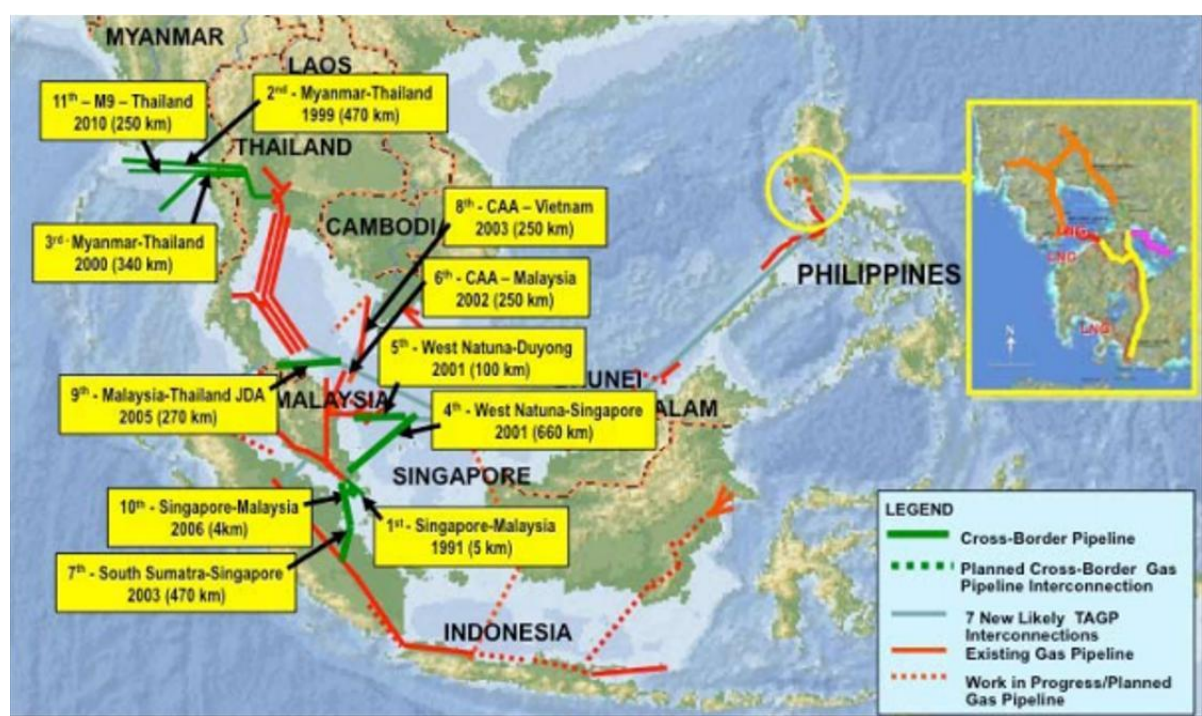

Figure 1. Trans ASEAN Gas Pipeline Route (ASEAN Secretariat, 2011).

Although ASEAN has designed a TAGP action plan which includes regional energy security measures, increasing integration of regional energy infrastructure, creating responsive regional energy policies that are gradual, and involving private sectors in efforts to secure regional energy reserves, this collaboration is not as smooth as we imagine. This inability to collaborate is due to economic inequality among member countries and policy inconsistencies that are not under existing reality (KESDM, 2013). In addition to these problems, there is a tendency for member countries to pay more attention to domestic gas needs, and because of that, the implementation of this project must be delayed $^{1}$ for four years. ${ }^{2}$

\subsection{Realism in TAGP}

The phenomenon of ASEAN countries that tend not to pay more attention to TAGP illustrates that the realist atmosphere in the region is still warm. The normative basis of realism is national security and the survival of the country; these are the values that drive the realist doctrine and realist foreign policy. Thus, the scope of the realists comes to the view that the state is the protector of its territory, its inhabitants, and its distinctive and valuable way of life. National interests are the final referee in determining foreign policy. Society and human morality are restricted to the state and do not extend to international relations, which is the political arena of major chaos and conflict disputes between countries where large powers dominate smaller parties (Jackson and Sørensen, 2009).

The fact that all countries must pursue their national interests indicates that the commitment of countries to an agreement will be difficult to achieve. All international agreements are temporary and conditional based on the interests and desires of countries. All countries must be prepared to abandon their international obligations, which means that treaties, conventions, customs, rules, and international law between countries are only in the form of wise arrangements that can and will be set aside if they conflict with national interests. Therefore, the interests of the state become the sole actor in embodying TAGP.

\footnotetext{
${ }^{1}$ Peter Roberts et al. (2003); Toby Carroll \& Benjamin Sovacool. (2008); Asia Pacific Energy Policy. (2011); Instituto Argentino Del Petróleo Y Del Gas. (2015); Anton Setiawan et al. (2016)

${ }^{2}$ Venkatachalam Anbumozhi and Kaliappa Kalirajan, (2017), in their book called Globalization of Low-Carbon Technologies: The Impact of Paris Agreement said that the energy ministers of the regional countries who are members of the ASEAN Ministers on Energy Meeting (AMEM) agreed to extend the deadline for the TAGP project to 2024. In addition there was an extension of the memorandum of understanding that was delivered in the article of Faisal Yunianto (2013).
} 


\begin{tabular}{|l|l|}
\hline 1. & $\begin{array}{l}\text { The nature and consequences of anarchy, realists reveal that anarchy requires states to pay } \\
\text { attention to the survival of their people whereas liberals argue that the threat to the } \\
\text { survival of the state is not enough to allow the creation of dominance in policymaking. }\end{array}$ \\
\hline 2. & $\begin{array}{l}\text { Prospect of international cooperation. Realists tend to be pessimistic, in contrast to the } \\
\text { liberal optimists. }\end{array}$ \\
\hline 3. & $\begin{array}{l}\text { The country's concern will be the debate between relative and absolute gains. Realists } \\
\text { perceive that the state tends to see the relative gains derived from other countries. Whereas } \\
\text { liberals tend to focus on absolute gains as their main goal. }\end{array}$ \\
\hline 4. & $\begin{array}{l}\text { Realists tend to focus on national security, while liberals tend to focus on absolute the } \\
\text { political economy. }\end{array}$ \\
\hline 5. & $\begin{array}{l}\text { Realists argue that the distribution of power is important compared to the intentions of a } \\
\text { country, while liberals emphasize the intentions of state decision-makers. }\end{array}$ \\
\hline
\end{tabular}

Figure 2. Realist's focus points (Baldwin, 1993).

Thus realists emphasize that countries should pay attention to their security as a consequence of an anarchic condition because other countries or their allies can be a threat. This view makes the concept of cooperation is difficult for realists to implement. The enormous pressure to maintain economic growth and the domestic fulfillment needs ultimately triggers each country to play its role. Indonesia, which has been exporting LNG to several ASEAN countries, is now beginning to reduce its supply because of their significant rise of domestic energy consumption. Indonesia is the largest country in natural gas needs in Southeast Asia reaching $44 \%$ of the total natural gas needs, followed by Malaysia at 23\% and Thailand 20\% (ASEAN Center for Energy, 2017). This demand came from the industrial sector that have been shifting their energy source from oil to gas. In 2012, there were only $60 \%$ of domestic industry gas needs that is fulfilled by domestic supply. This phenomenon is similar with Thailand and Malaysia, which also lead to a declining gas export. This atmosphere of realism will only lead into the way of difficulties in implementing the TAGP project.

Table 1. Indonesia LNG export in 2013-2017 (Trademap, 2018).

\begin{tabular}{ccccc}
\hline $\begin{array}{c}\text { Exported } \\
\text { value in } \\
2013\end{array}$ & $\begin{array}{c}\text { Exported } \\
\text { value in } \\
2014\end{array}$ & $\begin{array}{c}\text { Exported } \\
\text { value in } \\
2015\end{array}$ & $\begin{array}{c}\text { Exported } \\
\text { value in } \\
2016\end{array}$ & $\begin{array}{c}\text { Exported } \\
\text { value in } \\
2017\end{array}$ \\
\hline & & & & \\
$12,928,642$ & $11,704,464$ & $7,356,930$ & $5,146,437$ & $6,185,173$ \\
\hline
\end{tabular}

The Thai government has also stopped oil and natural gas exports to border countries such as Cambodia and Laos. ${ }^{3}$ Thailand took this measure because their demand of natural gas for electricity industry is increasing.

Table 2. Thailand LNG export in 2013-2017 (Trademap, 2018).

\begin{tabular}{ccccc}
$\begin{array}{c}\text { Exported } \\
\text { value in 2013 }\end{array}$ & $\begin{array}{c}\text { Exported } \\
\text { value in } \\
2014\end{array}$ & $\begin{array}{c}\text { Exported } \\
\text { value in } \\
2015\end{array}$ & $\begin{array}{c}\text { Exported } \\
\text { value in } \\
2016\end{array}$ & $\begin{array}{c}\text { Exported } \\
\text { value in } \\
2017\end{array}$ \\
\hline 273 & 99 & 143 & 3 & 33 \\
\hline
\end{tabular}

\footnotetext{
${ }^{3}$ Beny Suryadi (2015) in his article called Geopolitik Energi di Kawasan emphasize that this is related to the limitedness of domestic supply.
} 
In 2009 , more than $70 \%$ of Thailand gas consumption went to electricity generating plants, with the remaining $17 \%$ going to gas separation plants and $11 \%$ to industrial use. Although in 2009 Thailand was ranked 27th as one of the countries with the largest gas producer in the world, with 28.7 million $\mathrm{m} 3$ gas production, Thailand domestic gas source still not able to meet of domestic market. This fact leads to declining in export volume of Thailand Natural Gas. With the similar condition, the increasing gas production volume in Malaysia is not always have a good meaning for global gas market. Along with the high production volume, domestic demand also getting higher than previous years. This phenomenon is the result of the increasing of Malaysia population that lead to higher electrical need, $43.6 \%$ of domestic electric produced by gas. So that even though the volume of gas production increases, the trend of gas exports by Malaysia tends to have a downward trend in recent years.

Table 3. Malaysia LNG export in 2013-2017 (Trademap, 2018).

\begin{tabular}{ccccc}
\hline $\begin{array}{c}\text { Exported } \\
\text { value in } 2013\end{array}$ & $\begin{array}{c}\text { Exported } \\
\text { value in } \\
2014\end{array}$ & $\begin{array}{c}\text { Exported } \\
\text { value in } \\
2015\end{array}$ & $\begin{array}{c}\text { Exported } \\
\text { value in } \\
2016\end{array}$ & $\begin{array}{c}\text { Exported } \\
\text { value in } \\
2017\end{array}$ \\
\hline $18,890,616$ & $19,647,559$ & $12,082,690$ & $7,716,315$ & $9,361,535$ \\
\hline
\end{tabular}

Although Indonesia have abundant gas supply and one of the main drivers of the two agreements ratified on TAGP, this does not guarantee that the implementation of TAGP will run as expected. ${ }^{4}$ This uncertainty is inseparable from the obligation of a country to be responsible for the state of its domestic supply chain because the ultimate goal of foreign policy is to play a role in which it can fulfill national interests. Therefore, the state is an essential factor for the lives of its citizens: without a state that guarantees security tools and conditions, and that promotes well-being, human life will be limited, as stated in the famous Thomas Hobbes' statement, "remote, poor, very unpleasant, inhumane, and short" (Jackson and Sørensen, 2009).

This phenomenon suggests that the theory of realists is considered valid not only at a certain time but almost all the time because the basic fact of cooperation between ASEAN countries has never changed; this is what causes most realists to remain dissatisfied with the very weak thesis of liberals regarding treaties and international institutions. They stated that Keohane and many other institutionalist liberals ignored one crucial item, that is relative gains. Institutional liberals state that the institution facilitates collaboration and thus makes it a little unlikely that countries will cheat on one another; this is because the institution is transparent. Neorealists answer that cheating is not the main problem in negotiations between countries. The main problem is 'relative gains.' Countries must worry that other countries will benefit more from cooperation than they do themselves. The neorealists stated that institutional liberals did not pay attention to the issue, Grieco in Jackson and Sørensen (2009) implies that if we ignore the problem of relative gains, thus, we failed to recognize the main sources of state reserves regarding international cooperation.

\begin{tabular}{|l|l|}
\hline Absolute Gains & $\begin{array}{l}\text { As long as we do well, it does not matter if } \\
\text { others do even better. }\end{array}$ \\
\hline Relative Gains & $\begin{array}{l}\text { We will do our best, but number one priority is } \\
\text { that the others do not get ahead of us. }\end{array}$ \\
\hline
\end{tabular}

Figure 3. Absolute and Relative Gains (Jackson and Sørensen, 2009).

\footnotetext{
4 "Instrument to Extend the ASEAN Gas Pipeline Memorandum of Understanding on the TAGP Project" and "Protocol to the Amendment Agreement on the Establishment of the ASEAN Center for Energy" (ACE)
} 
From the figure above, we can see that the neorealist atmosphere has a role that is no less important than realist, where the relative gains is feared to occur when the cooperation of ASEAN countries through the TAGP scheme makes gas producing countries feel disadvantaged in terms of price and quantity to supply to member countries. In short, producer countries have suffered two losses, the reduction of domestic supply because they have been bound by contracts to supply gas to ASEAN countries and prices they do not favored. These disadvantages further explain the absence of absolute gains in the TAGP agreement. We have to put in mind that almost all of ASEAN member countries are natural gas suppliers, except Laos, Singapore, and Cambodia. The existence of many natural gas suppliers causes difficulties in regulating prices and creating dependency on natural gas commodities, resulting in some difficulties for gas producing country in expanding its market share and implementing a pressing political strategy. Even in recent years, Singapore has sought itself as the ruler of the natural gas supply chain in the region, facing competition from the plans of Thailand, Malaysia, and Indonesia which also built natural gas terminals. Aggravated by the attitude of Myanmar, which allocates their gas supply to China compared to ASEAN countries because China is more competitive in offering prices (Suryadi, 2015). Putting the TAGP project on hold until 2024 is necessary because the construction of this project is uncertain.

\subsection{Short Comparison on TAGP and Russia-Europe Gas Pipeline}

The author chose the Russian-European gas pipeline solely because of the similarities in the context of seriousness in building enormous infrastructure covering various regions. In 1959, Druzhba was the initial foundation of the Russian-European energy path with a length of around 4,000 km, built by the collaboration of the Union of Soviet Socialist Republics (USSR) and Hungary, Czechoslovakia, Poland, and the German Democratic Republic (Lee \& Connolly, 2016). Purely done because of the desire to reduce a large amount of cost of distribution via railways; this was the point that strengthens the dependence of Eastern and Central Europe on Soviet's oil and natural gas.

The Southeast Asia regional organization, ASEAN, has planned the process of integrating pipelines between member countries known as the TAGP scheme. This scheme will connect more than 3,000 $\mathrm{km}$ of gas pipelines. Planning for this scheme is an effort to build an ASEAN Community based on the economic pillar (ASEAN Economic Community), to maximize energy resources and energy security in Southeast Asia (ASEAN, 2008). It also provides an opportunity for the private sector to compete in terms of investment, financing, and technology transfer. Overall, the project was built to provide benefits in terms of security, energy supply quality, and flexibility.

Indeed, TAGP is not able to be juxtaposed with the Russian gas pipeline project. Washington had disrupted the Russian-European gas pipeline project, but in fact, the project's development went smoothly. This smooth development is because Russia is the largest and sole producer of natural gas supplies for the West European region, and it has resulted in the dependence of the European Union (EU) countries and regards Russia as a compatible trading partner. ${ }^{5}$ According to British Petroleum (2013) in its 2013 report BP Review of World Energy, Russia became the leader in the European region in terms of gas production and export. As a country that has large energy resources, especially in the gas sector, Russia plays a very important role for the sustainability of the economy and the survival of several countries in Europe, especially during the winter. Most European Union countries depend on their gas needs on Russia. Overall, EU countries are the biggest importer of natural gas in the world with a quantity of $64 \%$. Russia is currently distributing about two-thirds of its natural gas exports to many EU member countries and some non-EU countries (Perovic, Orttung \& Wenger, 2009). It is causing the project to have good progress. This successfulness is inseparable from Russia's domestic demand for gas, which has been able to be adequately fulfilled, making it easy for Russia to supply gas to the EU countries. Russia's existence as the biggest supplier is necessary for Western

\footnotetext{
${ }^{5}$ Andrew Monaghan (2005) in Conflict Studies Research Center: Russian Oil and EU Energy Security states that an agreement between the European Union and Russia regarding the gas trade began in 2000 (in the context of the EU's Green Paper on Energy Security) initiated by the France President, Jacques Chirac, together with Vladimir Putin and Commissioner Prodi. Russia and the European Union are partners in the energy sector and have similar interests in strengthening the overall energy security in the European continent.
} 
European countries in order to feel their gas necessities where both the supplier and consumer countries will, with all their might, make the pipeline project successful.

The phenomenon above results in an interdependence between countries - between consumer and producer countries. This term refers to the term that is polarized by Robert Keohane and Joseph Nye relating to complex transnational relations (interdependence) between countries or between societies. At present, interdependence relations between countries focus more on the economic sector. Economic interdependence is the economic relations between countries that are symmetrical (Awad, 2013). This symmetrical relationship means that both parties have an interdependent relationship that is balanced. However, sometimes unequal relationships can occur, an imbalance relationship occurs when one of the two trading partners is at a higher level of need than the other, then the country will then become vulnerable to the threat of exploitation, especially if they do not have other trading partners to fulfill their needs of goods and services (Keohane \& Nye, 1977). This phenomenon correlates with the analysis of the author regarding the role of state power that is needed to be able to survive and dominate other countries. The country's strengths were implemented through Russia's strategy to make the project successful because by expanding its gas market share to European market it was able to become a tool of political pressure if at any time there is friction between Western Europe and Russia.

\section{Conclusion}

The atmosphere of realism is strongly felt in the TAGP project because exporting countries were still demanding their gas supply for domestic needs - rather than building mutual interests through regional connectivity and energy security. The increase in gas consumption is in line with the economic growth of regional countries that need these resources as industrial sector. Their foreign policies, which are the embodiment of these conditions, produce difficulties in working together and resulting in the delays in the TAGP project. Also, there is a concern that the relative gains obtained if the producer countries implement TAGP policies also make this cooperation not run smoothly. The relative gains of 'overshadowing' the exporting countries are due to the nature of the international agreements themselves, which are difficult to achieve common interests. In addition to the loss of domestic supply, relative gains arise from the price of gas sales. These relative gains are inseparable because gas exporters do not consist of only one country, so it is challenging to create high prices. This condition is very different from Russian Gas Pipes, where Russia does not experience problems with domestic gas needs. So it causes their foreign policy to be cooperative in distributing gas to EU countries. Because of these conditions and supported by Russia, which became a significant player as a Gas exporter, it creates a complex interdependence. This symmetrical relationship means that both parties have a balanced interdependence relationship. However, if there is friction between the buyer and the seller, what is feared is that there will be political pressure and exploitation by exporters and it will be difficult for the importers to avoid because they have no other trading partners. 


\section{References}

Anastasia. (2017). Perekonomian ASEAN Membaik, Bisa Tumbuh 5,1\%. Media Indonesia. Retrieved from: $\quad$ http://mediaindonesia.com/read/detail/102610-perekonomian-asean-membaik-bisatumbuh-5-1.

Anbumozhi, V., \& Kalirajan, K. (2017). Globalization of Low-Carbon Technologies: The Impact of Paris Agreement. Singapore: Springer Nature.

ASEAN. (2008). ASEAN Economic Community Blueprint. Jakarta: ASEAN Secretariat.

ASEAN Center for Energy. (2017). The 5th ASEAN Energy Outlook. Retrieved from: http://www.aseanenergy.org/resources/the-5th-asean-energy-outlook/.

ASEAN Council on Petroleum. (2015). Trans ASEAN Gas Pipeline Project. Retrieved from: http://www.ascope.org/Projects/Detail/1060.

ASEAN Secretariat. (2011). Master Plan on ASEAN Connectivity. Retrieved from: https://policy.asiapacificenergy.org/sites/default/files/Master_Plan_on_ASEAN_Connectivity.p df.

Baldwin, D.A. (1993). Neorealism and Neoliberalism: The Contemporary Debate. New York: Columbia University Press.

British Petroleum. (2014). BP Statistical Review of World Energy 2013. Retrieved from: http://large.stanford.edu/courses/2013/ph240/lim1/docs/bpreview.pdf.

Carrol, T., \& Sovacool, B. (2008). Contested regionalism in Southeast Asia: the politics of the transASEAN Gas Pipeline Project. Singapore: Center on Asia and Globalization.

Instituto Argentino Del Petróleo Y Del Gas. (2015). The Trans ASEAN Gas Pipeline- Accelerating Gas Market Integration Within The ASEAN Region. Retrieved from: shttp://www.iapg.org.ar/WGC09/admin/archivosNew/Special\%20Projects/3.\%20IGU\%20GMI \%20Guidelines/3.\%20IGU\%20GMI\%20Guidelines\%20FINAL\%20-

$\% 20 \mathrm{CD} \% 20$ contents/Transasean.pdf.

Jackson, R., \& Sørensen, G. (2009). Introduction to International Relations. New York: Oxford University Press.

Kementerian Energi dan Sumber Daya Mineral (KESDM) Republik Indonesia. (2013). Indonesia Tuan Rumah Pertemuan Menteri Energi Se-ASEAN Ke-31. Retrieved from: https://www.esdm.go.id/id/media-center/arsip-berita/indonesia-tuan-rumah-pertemuan-menterienergi-se-asean-ke-31.

Kementerian Luar Negeri. (2015). ASEAN Selayang Pandang edisi ke-21. Jakarta: Kementerian Luar Negeri-Sekretariat Direktorat Kerjasama ASEAN.

Lee, J., \& Connolly, D. (2016). Pipeline Politics between Europe and Russia: A Historical Review from the Cold War to the Post-Cold War. The Korean Journal of International Studies, 14(1), 105-129.

Monaghan, A. (2005). Conflict Studies Research Centre: Russian Oil and EU Energy Security. England: Defence Academy of the United Kingdom.

Perovic, J., Orttung, R. W., \& Wenger, A. (2009). Russian Energy Power and Foreign Relation: Implication for Conflict and Cooperation. London: Routledge.

Roberts, P., et al. (2003). Building the Trans ASEAN Gas Pipeline. Hong Kong: Asia Pacific Review.

Setiawan, A. et al. (2016). The Complexities of Programme Management: Case Study of Trans ASEAN Gas Pipeline. PM World Journal. Accessed from https://pmworldjournal.net/wpcontent/uploads/2016/01/pmwj46-May2016-Complexities-of-Programme-Management-TransASEAN-Gas-Pipeline-case-study.pdf.

Suryadi, B. (2015). Geopolitik Energi di Kawasan. Bicara Energi. Retrieved from: http://bicaraenergi.com/2015/01/geopolitik-energi-di-kawasan/.

Trade Map. (2018). List of importing markets for a product exported by Indonesia Metadata. Retrieved from https://www.trademap.org/Country_SelProductCountry_TS.aspx?nvpm=1\%7c360\%7c\%7c\%7c $\% 7 \mathrm{c} 2711 \% 7 \mathrm{c} \% 7 \mathrm{c} \% 7 \mathrm{c} 4 \% 7 \mathrm{c} 1 \% 7 \mathrm{c} 1 \% 7 \mathrm{c} 2 \% 7 \mathrm{c} 2 \% 7 \mathrm{c} 1 \% 7 \mathrm{c} 2 \% 7 \mathrm{c} 1 \% 7 \mathrm{c} 1$.

Trajano, J., \& Vineles, P. (2016) Road to Low-Carbon ASEAN Community. Singapore: $S$. Rajaratnam School of International Studies. 
Yunianto, F. (2013). ASEAN Lanjutkan Bangun Jaringan Pipa Gas. Retrieved from: https://www.antaranews.com/berita/397422/asean-lanjutkan-rencana-bangun-jaringan-pipa-gas.

Zubacheva, K. (2017). Tiga Produk Yang Ternyata Diimpor Rusia. Russia Beyond the Headline (RBTH). Retrieved from: https://id.rbth.com/economics/79449-produk-impor-tak-diduga-qyx. 